\title{
PERAN PESANTREN DALAM MENGEMBANGKAN PENDIDIKAN KARAKTER
}

\author{
Fauzan \\ Dosen STAI (Sekolah Tinggi Agama Islam) Al-Khairat Pamekasan \\ Email:masfauzan@gmail.com
}

\begin{abstract}
Abstrak:
Pesantren merupakan lembaga yang secara konsisten mengajarkan konsep pendidikan karakter. Pendidikan karakter yang sarat dengan etika atau akhlak menjadi ciri khas pesantren. Pendidikan karakter yang mewarisi pesantren dalam pembetukan watak, kepribadian, budi pekerti, dan lainnya tercermin dalam rutinitas pendidikan yang berlangsung hampir 24 jam dimulai ketika mereka bangun di pagi hari hingga menjelang tidur di malam hari. Rentetan aktifitas santri di pesantren mencakup tiga aspek kognitif, afektif, dan psikomotorik yang terintegrasi ke dalam kekokohan jiwa mereka menjadi benteng kekuatan dan menjadi bekal ketika mereka kembali ke lingkungannya masingmasing. Realitas aktifitas di pesantren yang terjadi secara berkesinambungan telah menanamkan karakter-karakter yang menjadi identitas santri. Inilah sisi keberhasilan pesantren dalam penanaman pendidikan karakter, karena pada prinsipnya penanaman karakter akan lebih efektif melaui pembiasaan dan teladan yang diawasi langsung oleh gurunya.
\end{abstract}

Kata kunci: Pesantren, Pendidikan Karakter, Santri

Abstract:

Pesantren is an instution which consistently teaches charater education concept. Character education similar to ethic and character is a thew of pesantren. Character education which characterizes pesantren in forming character and personality, and so forth, reflected in daily education routines progressing in almost 24 hours started in the morning when they get up untill they sleep at night. The series of santri's activities in pesantren are consist of three aspects namely cognitive, affective, and psychomotoric that integrated in their robustness soul become a power and become a subject when they comeback to their environment themselves. The reality of their activities in pesantren which sustainably happened have implemented 
characters become santri's identity. This is the side of pesantren's success in implementing character education, because principally the implementation of character will be more effective with habituation and giving example supervised directly by their teacher.

Keywords: pesantren, character education, santri

\section{Prolog}

Tidak dapat dipungkiri bahwa sejarah pesantren di Indonesia melatarbelakangi historis berdiri dan berkembangnya pendidikan di Indonesia. Hal ini dibuktikan dengan banyaknya ulasan tentang pesantren yang merupakan cikal-bakal pendidikan di Indonesia.

Dikatakan bahwa pesantren merupakan pendidikan Islam tertua yang merupakan produk budaya Indonesia. Keberadaan pesantren di Indonesia dimulai sejak Islam masuk Indonesia dengan mengadopsi sistem pendidikan keagamaan yang sebenarnya telah lama berkembang sebelum kedatangan Islam. Sebagai lembaga pendidikan yang telah lama berurat akar di negeri ini, diakui memiliki andil yang sangat besar terhadap sejarah bangsa. ${ }^{1}$

Kehadiran pesantren di Indonesia telah memberikan kontribusi yang luar biasa terhadap pembangunan Indonesia, dimana sejak awal berdirinya, pesantren telah banyak melahirkan tokoh-tokoh nasional yang mampu berkiprah dalam pembangunan bangsa, terbukti dengan banyaknya alumni pesantren yang menempati posisi strategis, baik di tingkat daerah hingga pusat. Fakta ini cukup memberikan bukti bawa pesantren dapat melahirkan output yang matang dan siap berkompetisi di dunianya masing-masing.

Prestasi pesantren dalam dunia pendidikan juga tidak bisa diremehkan, karena amat banyak santri yang prestasinya membanggakan baik di area lokal maupun internasional. Berbicara prestasi tentunya tidak lepas dari sistem pendidikan yang dijalankan di pesantren dan karakter yang membentuk mental santri menjadi kuat sehingga mampu berkompetisi di luar dan mampu berkiprah di dunia nyata. Namun prestasi akademik pesantren bukan satu-satunya kebanggaan, karena poin-poin yang banyak ditunjukkan oleh para ahli dan peneliti tentang kelebihan pesantren adalah keberhasilan pesantren dalam membentuk karakter santrinya.

Keberhasilan pesantren dalam membentuk karakter santri tidak terlepas dari totalitas pendidikannya yang terintegrasi dalam kegiatannya yang berlangsung selama hampir 24 jam yang mampu mensinergikan ranah kognitif, afektif, dan psikomotorik sehingga menjadikan santri memiliki

\footnotetext{
${ }^{1}$ Haedari dan H. Amin, Transformasi Pesantren, (Jakarta: Media Nusantara, 2007), 3
} 
kecakapan yang cukup, mental yang tangguh, dan berkarakter. Karakter yang terbentuk pada diri santri merupakan nilai afektif yang terbentuk dari tuntutan agama yang mewajibkan umat muslim menuntut ilmu dan apresiasi tinggi yang diberikan kepada penuntut ilmu.

Islam memberikan penghargaan yang tinggi terhadap ilmu. Ilmu yang dimaksud di sini adalah imu amaliah. Artinya, seseorang yang memperoleh ilmu akan dianggap berarti jika ia mau mengamalkan ilmunya. Al-Ghazāli mengatakan bahwa manusia seluruhnya akan hancur, kecuali orang yang berilmu, semua orang yang berilmu akan hancur, kecuali orang-orang yang beramal, semua orang-orang yang beramal akan hancur kecuali orang-orang yang ikhlas dan jujur. Al-Ghazāli memandang pendidikan sebagai teknik, bahkan sebagai sebuah ilmu yang bertujuan memberi manusia pengetahuan dan watak yang dibutuhkan untuk mengikuti pentunjuk Tuhan. ${ }^{2}$

Pesantren adalah salah satu lembaga yang menjadi pusat pengembangan ilmu. Berbagai teori keilmuan dari berbagai disiplin ilmu yang dikaji di pesantren menjadi acuan untuk dipraktekkan. Kecenderungan untuk mempraktekkan nilai-nilai teoritis yang diperoleh santri dari kajiankajiannya adalah sebuah sebuah keniscayaan karena dalam konteks keIslaman ilmu dikatakan bermanfaat kalau diamalkan. Nilai amaliah inilah yang membedakan dirinya dari entitas-entitas lainnya yang menempatkannya pada posisi sebagai khalifah di muka bumi. Dan hasil terbesar yang akan diperoleh adalah pengetahuan tentang Tuhan yang terimpleme-ntasikan dalam nilai praktisnya. Nilai praktek inilah yang mempengaruhi pembentukan karakter pada santri yang menempatkan dirinya pada nilai kemuliaan.

Kemuliaan syariah sebagai realitas perilaku moral adalah pentransformasian sifat-sifat Tuhan dalam dirinya yang terealissi dalam perilakunya secara ikhlas. ${ }^{3}$ Al-Ghazāli melalui karyanya yang berjudul Mizān al-'Amal dan Ihyā' 'Ulüm al-Dīn berusaha menempatkan pembaca karyanya pada pusat permasalahan etika. Ia menegaskan, kebahagiaan merupakan nilai yang dicari semua orang. Kebahagiaan akan terwujud jika ada ketekaitan antara pengetahuan (ilm) dan perbuatan ('amal). ${ }^{4} \mathrm{Nah}$, pesantren menjadi salah satu lembaga refresentatif yang dapat memadukan pengetahuan dan praktek yang berlangsung secara berkesinambungan.

\footnotetext{
${ }^{2}$ Bustami A Gani dan Djohar Bahry, Dasar-Dasar Pokok Pendidikan Islam, (Jakarta: Bulan Bintang, 1987), 46.

3 Masnur Muslich, Pendidikan Karakter Menjawab Tantangan Krisis Multidimensional, (Jakarta: PT Bumi Aksara, 2011), 49.

${ }^{4}$ Majid Fakhry, Etika dalam Islam, Terjemah oleh Zakiyuddin Baidlawi, (Yogyakarta: Pustaka Pelajar, 1996), 126.
} 
Nilai-nilai pendidikan di pesantren sejalan dengan prinsip-prinsip dalam Islam yang kemudian dijabarkan oleh para ulama. Tiga prinsip dasar yang mutlak ada di pesantren yaitu akidah, syariat, dan akhlak. Ketika prinsip ini melebur menjadi sebuah kekuatan dalam jiwa santri sehingga membentuk karakter dalam dirinya.

Sejatinya, pesantren dengan berbagai elemen pendidikannya adalah lembaga yang mampu mengembangkan pendidikan karakter secara lebih maksimal. Hal ini tercermin dari penanaman nilai teoritis yang didapatinya dari kajian-kajiannya ke dalam bentuk praktek-praktek kesehariannya. Mereka dapat mentransfer nilai-nilai teoritis yang didapatinya dari kajiankajian kitab ke dalam bentuk paktek secara simultan. Kebiasaan itu dapat membentuk karakter secara alamiah tanpa terasa.

Keberhasilan pesantren dalam membentuk karakter mengun-dang banyak lembaga lainya untuk meniru desain pesantren. Buktinya, banyak lembaga-lembaga yang meniru formulasi pesantren dengan mendirikan pendidikan berasrama. Mereka meyakini bahwa konsep pendidikan berasrama seperti pesantren benar-benar mampu membentuk karakter anak didiknya. Karena karakter yang tertanam dalam diri santri sebagai buah aplikasi nilai teori bukan sekadar keterampilan atau kemampuan instingnya, tetapi kemampuan untuk mempertahankan nilai-nilai kesantriannya berdasarkan ontologis pesantren berdasarkan al-Qur'an dan Hadis, sehingga ketika santri berkiprah di masyarakat mempunyai keteguhan untuk mempertahankan nilai-nilai religiusnya.

\section{Hakikat Pesantren}

Eksistensi pesantren yang unik dan penuh ragam karakteristik dengan sistem yang kompleks telah memuculkan penilaian para peneliti dan pengamat. Ragamnya penialain ini muncul karena berangkat dari sudut pandang yang berbeda dilihat dari peran dan kiprah pesantren yang dianggap sebagai produk budaya Indonesia yang indigenous ${ }^{5}$.

KH. Hasani Nawawie ${ }^{6}$ memberikan definisi pesantren sesuai dengan esensi dan fungsi fundamentalnya. Bahwa pesantren adalah lembaga yang berfungsi untuk membentuk para anggotanya agar bertakwa kepada Allah Swt. Sebagaimana didirikannya masjid yang berfungsi untuk membangun

\footnotetext{
${ }^{5}$ Pesantren tidak hanya identik dengan nama keIslaman, tetapi juga mengandung makna keaslian indonesia yang muncul dan berkembang dari pengalaman sosiologis masyarakat sekitarnya.

${ }^{6}$ Penasehat Majelis Keluarga Pondok Pesantren Sidogiri Pasuruan Jawa Timur, wafat 2001 M.
} 
ketakwaan bagi setiap individu Muslim, maka demikian pula pesantren juga sebangun dengan asas yang membentuk masjid. ${ }^{7}$

Maka pesantren sejak asas dan fondasi, visi dan misi, proses pendidikan, hingga target yang ingin dicanangkan oleh pesantren, adalah benar-benar seriring dengan prinsip-prinsip Islam atau tuntutan al-Qur'an dan Hadis. Oleh karena itu sifat dan karakter yang mutlak harus dimiliki oleh santri sebagai salah satu objek pesantren adalah sifat dan karakter sebagaimana yang tertuang dalam al-Qura'an dan Hadis yaitu tertanamnya sifat dan karakter mulia yang dinamakan akhlak mahmudah. Penanaman nilai-nilai ini menjadi salah satu yang mencirikan pesantren, sehingga tidak salah bila dikatakan bahwa pesantren sebagai lembaga pembentuk mental.

Dilihat dari posisi kelembagaannya, pesantren bermakna sebagai lembaga pendidikan yang tetap istiqamah melakukan perannya sebagai pusat pendalaman ilmu-ilmu agama (tafaqquh fi al-din) dan lembaga dakwah Islamiyah serta ikut mencerdaskan kehidupan masyarakat, dibuktikan dengan keberhasilannya dalam mencetak tokoh-tohoh agama, pejuang bangsa serta tokoh masyarakat, baik di masa pra-kemerdekaan, setelah kemerdekaan maupun di zaman sekarang. ${ }^{8}$

Dari definisi di atas dapat disimpulkan bahwa pesantren adalah lembaga pendidikan yang lebih represetatif untuk mempelajari ajaran-ajaran ilmu Islam secara total dan integral. Pesantren menjadi tempat yang pantas bagi yang ingin mempelajari ajaran dan ilmu Islam karena beberapa alasan yaitu: 1). Pesantren merupakan rujukan bagi ajaran-ajaran Islam yang terjamin validitasnya. 2). Pesantren memegang kokoh prinsip yang telah diajarkan Islam dan diwariskan ulama salaf yang sholeh dari periode ke periode berikutnya hingga saat ini. 3 ). pesantren mengajarkan ajaran dan ilmu Islam secara komprehensif, total, dan menyeluruh.

Pada masa awal, pesantren memiliki tingkat yang berbeda-beda. Tingkat paling sederhana hanya mengajarkan cara membaca huruf Arab dan al-Quran. Pesantren yang agak tinggi mengajarkan berbagai kitab Fikih, Ilmu Akhlak, tata Bahasa Arab (Nahwu Sarf). Perkembangan awal pesantren inilah yang menjadi cikal-bakal dan tipologi unik pesantren yang berkembang hingga saat ini.

Pada perkembangan selanjutnya, pada paruh kedua abad ke-20, ada dorongan arus besar dari pendidikan ala Barat yang dikembangkan pemerintah Belanda dengan mengenalkan sistem sekolah. Kenyataan ini

\footnotetext{
7 Tim Penulis Pustaka Sidogiri, Mengapa Saya Harus Mondok di Pesantren?( Pasuruan: Pustaka Sidogiri, 2008), 184.

8 Abdullah Syukri Zarkasyi, Gontor dan Pembaharuan pendidikan Pesantren (Jakarta: PT Raja Grapindo Persada, 2005), 1.
} 
direspon secara positif oleh pemimpin-pemimpin Islam dengan memperkenalkan sistem pendidikan berkelas dan berjenjang dengan nama "Madrasah" (yang dalam beberapa hal berbeda dengan sekolah). Walau perkembangan ini tidak mempengaruhi banyak pesantren, karena tidak semua pesantren mengikuti perubahan tersebut karena masih ada yang merasa tabu dengan pola Barat. Namun sudah ada beberapa pesantren yang memasukkan unsur-unsur pendidikan umum ke dalam kurikulum pesantren, seperti Pesantren Mambaul Ulum Surakarta, Pesantren Tebu Ireng Jombang, dan Pesantren Modern Darussalam Gontor. Secara umum pesantren tetap bertahan dengan karakteristiknya yang khas hingga dekade 1960-an. ${ }^{9}$

Memasuki era 1970-an pesantren mengalami perubahan signifikan. Peubahan itu dilihat dari dua faktor yaitu (1) pesantren mengalami perkembangan kuantitas yang cukup menakjubkan, (2) penyelenggaraan pendidikan di pesantren sudah bervariasi. Bentuk-bentuk pendidikan diklasifikasikan menjadi empat tipe, yakni (1) pesantren yang hanya mengajarkan ilmu-ilmu agama dalam bentuk Madarasah Diniyah (MD), (2) pesantren yang hanya sekedar menjadi tempat pengajian, (3) pesantren yag menyelenggarakan pendidikan formal dengan menerapka kurikulum nasioal, baik yang hanya memiliki sekolah keagamaan (MI, MTs, MA) maupun yang memiliki sekolah umum (SD, SMP, SMU), dan (4) pesantren yang menyelengarakan pendidikan keagamaan dalam bentuk madrasah dan megajarkan ilmu-ilmu umum meskipun tidak menerapkan kurikulum nasional.

Namun demikian, perubahan yang terjadi pada pesantren sama sekali tidak mencerabut pesantren dari akar kulturalnya, karena perubahan pesantren hanya berpengaruh pada aspek perannya. Secara umum pesantren tetap mampu mempertahankan fungsi dasarnya sebagai (1) lembaga penddidikan yang melakukan transfer ilmu-ilmu agama (tafaqquh fí al-din) dan nilai Islam (Islamic values), (2) lembaga keagamaan yang melakukan kontrol sosial (social control), dan (3) lembaga keagamaan yang melakukan rekayasa sosial (social engineering).

Kemampuan pesantren untuk mempertahankan fungsi dasar inilah yang menajadikan pesantren memiliki ciri khas dan memiliki prinsip yang melekat pada pendidikan pesantren. Nurcholis Madjid menjelaskan setidaknya ada dua belas prinsip yang melekat pada pendidikan pesantren yaitu:

a) Teosentrik;

\footnotetext{
${ }^{9}$ M. Sulthon dan Moh. Khusuridlo, Manajemen Pondok Pesantren dalam Persefektif Global, (Ygyakarta: LaksBang PRESSindo, 2006), 6.
} 
b) Ikhlas dalam pengabdian;

c) Kearifan;

d) Kesederhanaan;

e) Kolektifitas (Barakat al-jamā'ah);

f) Mengatur kegiatan bersama;

g) Kebebasan terpimpin;

h) Kemandirian;

i) Tempat menuntut ilmu dan mengabdi

j) Mengajarkan ajaran agama;

k) Belajar di pesantren bukan untuk mencari sertifikat/ijazah saja; dan

1) Kepatuhan terhadap kiai. ${ }^{10}$

Percepatan perubahan zaman memberikan ruang bagi pengelola pesantren untuk berbenah dan melebarkan visi dan misinya. Tentunya tujuan pendidirian pesantren pada masa dasawarsa yang berbeda juga memiliki arah dan ruang lingkup yang berbeda pula. Misalnya pada awal berdirinya pesantren pada masa penjajahan sekedar menyelenggarakan kajian-kajian ilmu agama dengan menggunakan sistem pengajaran tradisional yaitu sorogan dan wedonan atau bandongan yang menjadi ciri khasnya. Aktifitas pengajaran biasanya dilakukan di masjid- masjid, langgar atau di rumah kiai. Sorogan adalah cara belajar individual dimana santri menghadap guru seorang demi seorang dengan membawa kitab yang diperlajarinya, sedangkan wedonan atau bandongan adalah model pembelajaran dimana santri mengikuti pelajaran dengan duduk di sekitar guru, sementara guru menerangkan pelajaran secara kuliah dengan terjadwal.

Pada perkembangan selanjutnya, pesantren mengalami tantangan yang semakin berat seiring dengan perubahan zaman yang cepat dan tuntutan kehidupan yang semakin tinggi. Kemajuan dunia tentunya memberikan manfaat tersendri bagi eksistensi pesantren, namun juga memberikan tantangan tersendiri untuk membentengi santrinya dari pengaruh negatif tersebut. Salah satu contoh misalnya kehadiran sarana informasi dan teknologi (IT) bukan sekadar memberikan manfaat positif, tetapi juga dapat melahirkan dampak negatif terutama terhadap perubahan mental dan akhlak. Selanjutnya searah dengan perubahan zaman, tuntutan hidup yang semakin meningkat, pesantren juga perlu mengantisipasinya dengan menyiapkan langkah-langkah strategis berupa program-program yang menjembatani antara tuntutan zaman dengan kebutuhan masyarakat.

\footnotetext{
${ }^{10}$ Abudin Nata, Sejarah Pertumbuhan dan Perkembangan Lembaga-Lembaga Pendidikan Islam di Indonesia, (Jakarta: PT. Grasindo, 2001), 113.
} 
Pesantren juga dituntut untuk menyiapkan peserta didiknya menjadi manusia yang tidak hanya memiliki kompetensi keilmuan yang memadahi, tetapi juga menjunjung tinggi aspek moral sebagai landasan berpijak.

\section{Pendidikan Karakter di Pesantren}

Pendidikan adalah proses internalisasi budaya ke dalam diri seorang dan masyarakat sehingga membuat orang dan masyarakat jadi beradab. Pendidikan bukan sekadar transfer ilmu pengetahuan saja, tetapi dalam arti yang lebih luas, yaitu sebagai sarana pembudayaan dan penyaluran nilai (enkulturisasi dan sosioalisasi). Anak didik harus mendapatkan pendidikan yang menyentuh dimensi dasar kemanusiaan. Dimensi kemanusiaan itu mencakup tiga hal paling mendasar, yaitu (1) afektif, yang tercermin pada kualitas keimanan, ketakwaan, akhlak mulia termasuk budi pekerti luhur serta kepribadian unggul, dan kompetensi estetis; (2) kognitif, yang tercermin pada kapasitas pikir dan daya intelektualitas untuk menggali dan mengembangkan serta menguasasi ilmu pengetahuan dan teknologi; dan (3) psikomotorik yang tercermin pada kemampuan mengembangkan keterampilan teknis, kecakapan praktis, dan kompetensi kinestetis. ${ }^{11}$ Dengan demikian pendidikan adalah membangun karakter, yang secara implisit mengandung arti membangun sifat atau pola perilaku yang didasari atau berkaitan dengan dimensi moral yang positif.

Karakter dalam kamus Bahasa Indonesia, diartikan dengan tabiat, sifat-sifat kejiwaan, watak, dan akhlak atau budi pekerti yang membedakan seeorang dengan yang lain. Dengan demikian orang berkarakter berarti orang yang berkepribadian, berperilaku, bersifat, bertabiat, atau berwatak.

Menurut Simon Philips dalam buku Refleksi Karakter Bangsa, karakter adalah kumpulan tata nilai yang menuju pada suatu sistem, yang melandasi pemikiran, sikap, dan perilaku yang ditampilkan. ${ }^{12}$ Lickona mengemukakan bahwa karakter adalah a reliable inner disposition to respond to situations in a morally good way, ${ }^{13}$ yang berarti suatu watak terdalam untuk merespon situasi dalam suatu cara yang baik dan bermoral. Imam Ghazāli menganggap bahwa karakter lebih dekat dengan akhlak, yaitu spontanitas manusia dalam bersikap, atau perbuatan yang telah menyatu dalam diri manusia sehingga ketika muncul tidak perlu dipikirkan lagi.

\footnotetext{
${ }^{11}$ Masnur Muslich, Pendidikan, (Jakarta: PT Bumi Aksara, 2011), 67.

${ }^{12}$ Saifuddin, Achmad Fedyani dan Karim, Mulyawan, Refleksi Karakter Bangsa, (Jakarta: Forum Kajian Antropologi Indonesi a, 2008), 235.

13 Thomas Lickona, Educating for Character: How Our School Can Teach Respect and Responsibility, (New York; Bantam Books, 1991), 51.
} 
Dengan makna seperti itu, berarti karakter identik dengan kepribadian atau akhlak. Karakter merupakan nilai-nilai perilaku manusia yang universal yang meliputi aktifitas manusia baik dalam rangka berhubungan dengan Tuhan, diri sendiri, sesama manusia, maupun lingkungan, yang terwujud dalam pikiran, sikap, perasaan, perkataan, dan perbuatannya berdasarkan norma-norma agama, hukum, tatakrama, budaya, dan adat istiadat.

Dari konsep karakter ini muncul pendidikan karakter. Konsep pendidikan karakter mulai dikenalkan pada tahun 1990-an. Thomas Lickonalah yang dianggap sebagai tokoh yang mempopulerkan konsep pendidikan karakter, terutama ketika ia menulis bukunya yang berudul Educating for Character: How Our School Can Teach Respect and Responsibility (1991) yang kemudian disusul oleh tulisan-tulisannya, seperti "The Return of Character Education" yang dimuat dalam jurnal Educational Leadership (1993), dan Eleven Principles of Effective Character Education" yang dimuat dalam Journal of Moral (1996), serta buku Character Matters: How to Help Our Children Develop Good Judgment, Integrity, and Other Essential Virtues (2004). ${ }^{14}$

Untuk dapat memahami pendidikan karakter itu sendiri, kita perlu memahami struktur antropologis yang ada dalam diri manusia. Stuktur antropologis manusia terdiri atas jasad, ruh, dan akal. ${ }^{15}$ Hal ini selaras dengan pendapat Lickona yang menekankan tiga komponen karakter yang baik, yaitu moral knowing (pengetahuan tentang moral), moral feeling (pengentahun tentang moral), dan moral action (perbuatan moral) yang diperlukan agar anak mampu memahami, merasakan, dan mengerjakan nilainilai kebajikan. Istilah lainnya adalah kognitif, afektif, dan psikomotorik. Untuk itu dalam pendidikan karakter harus mencakup semua struktur antropologis manusia tersebut. ${ }^{16}$

Moral knowing merupakan hal yang penting untuk diajarkan. Moral knowing ini terdiri dari enam hal, yaitu: (1) moral awareness (kesadaran moral), (2) knowing moral values (mengetahui nilai-nilai moral), (3) perspektif taking, (4) moral reasoning (5) decision making, dan (6) self knowledge.

Moral feeling adalah aspek yang lain yang harus ditanamkan kepada anak yang merupakan sumber energi dari diri manusia untuk bertindak sesui dengan prinsip-prinsip moral. Terdapat enam hal yang merupakan aspek emosi yang harus mampu dirasakan oleh seseorang untuk menjadi manusia

\footnotetext{
${ }^{14}$ Marzuki, Pendidikan Karakter Islam, (Jakarta: Amzah, 2015), 22.

15 Doni Koesoema, Pendidikan Karakter: Strategi Mendidik Anak di Zaman Mo-dern, (Jakarta: PT Gasindo, 2007), 80.

${ }^{16}$ Masnur Muslich, Pendidikan, (Jakarta: PT Bumi Aksara, 2011), 75-76.
} 
berkarakter, yakni (1) conscience (nurani), (2) self esteem (percaya diri), (3) empathy (merasakan penderitaan orang lain), (4) loving the good (mencintai kebenaran), (5) self control (kemampuan mengontrol diri, dan (6) humility (kerendahan diri).

Moral action adalah bagaimana membuat pengetahuan moral dapat diwujudkan menjadi tindakan nyata. Perbuatan tindakan moral ini merupakan hasil (outcome) dari dua komponen karakter lainnya. Untuk memahami apa yang mendorong seseorang dalam perbuatan yang baik (act morally) maka harus dilihat tiga aspek lain dari karakter, yaitu kompetensi (competence), keinginan (will), dan kebiasaan (habit).

Pendidikan karakter ini harus dipahami sebagai upaya penanaman kecerdasan dalam pikiran, penghayatan dalam bentuk sikap dan pengamalan dalam bentuk perilaku yang sesuai dengan nilai luhur yang menjadi jati dirinya, diwujudkan dalam interaksi terhadap Tuhannya, diri sendiri, antar sesama, dan lingkungannya. Nilai-nila luhur tersebut antara lain kejujuran, kemandirian, sopan santun, kemuliaan sosial, kecerdasan berfikir, dan berfikir logis. Oleh karena itu pendidikan karakter tidak bisa hanya mentransfer pengetahuan atau melatih suatu keterampilan tertentu, tetapi penanaman karakter perlu proses, contoh keteladanan, dan pembiasaan atau pembudayaan dalam lingkungan peserta didik, baik lingkungan pendidikan, keluarga maupun masyarakat.

Melihat makna pendidikan karakter di atas, maka sangat tepat jika pesantren sebagai lembaga pendidikan, dikatakan sebagai salah satu lembaga yang menjalankan konsep pendidikan karakter. Hal ini dapat dilihat karena muatan-muatan konsep pendidikan karakter seperti yang diutarakan tokoh-tokoh di atas sudah termaktub dalam dialektika pendidikan di pesantren.

Abdullah Syukri Zarkasyi ${ }^{17}$ menyatakan bahwa pesantren mempunyai keunggulan dan karasteristik khusus dalam mengaplikasikan pendidikan bagi anak didiknya (santri). Hal itu dikarenakan:

1. Adanya jiwa dan falsafah

Jiwa dan falsafah yang ditanamkan kepada santri akan menjamin kelangsungan lembaga pendidikan bahkan menjadi motor penggerak bagi seluruh penghuni pesantren. Diantara falsafah itu yaitu Panca Jiwa yang terdiri dari; (a) keihklasan, (b) kesederhanaan, (c) kemandirian, (d) ukhuwah Islamiyah, dan (e) kebersamaan dalam menentukan lapangan perjuangan dan kehidupan.

17 Pemimpin Pondok Modern Darussalam Gontor Ponorogo mulai tahun 1985 hingga sekarang. 
2. Terwujudnya integralitas dalam jiwa, nilai, sistem dan standar operasional pelaksanaan

Terciptanya integralitas yang solid pada jajaran para pendidik hingga anak didik, terhadap pemahaman jiwa, nilai, visi, misi dan orientasi, sistem hingga standar operasional pelaksanaan yang sama, sehingga mampu memadukukan seluruh komponen pesantren dalam satu barisan.

3. Terciptanya tri pusat pendidikan yang terpadu

Tri pusat pendidikan terpadu merupakan tiga faktor yang menopang dan mendukung keberhasilan pendidikan yang terdiri dari pendidikan sekolah, pendidikan keluarga, dan pendidikan masyarakat.

4. Totalitas pendidikan

Pesantren menerapkan totalitas pendidikan dengan mengandalkan keteladanan, penciptaan lingkungan dan pembiasaan melalui berbagai tugas dan kegiatan. ${ }^{18}$

Rutinitas pendidikan di pesantren yang berlangsug selama hampir 24 jam mencerminkan totalitas pendidikan yang mencakup tiga aspek pendidikan yaitu kognitif, afektif, dan psikomotorik. Melihat rentetan aktifitas santri di pesantren mulai dari bangun pagi hingga tidur di malam hari, memungkinkan karakter lebih mudah tertanam dalam diri santri karena nilai pendidikan yang diterima santri dari ketiga aspek pendidikan telah terimplementasikan dalam dialektika kehidupannya. Ditambah lagi dengan penanaman karakter keagamaan yang kuat dengan pengawasan yang ketat sehingga santri diharapkan mempunyai karakter agama yang kuat, mengamalkan nilai-nilai ajaran agama dengan baik, memiliki akhlak sesuai dengan ajaran Islam, serta mampu memaknai kehidupan berdasarkan alQur'an dan Hadis.

Pembelajaran karakter yang tertanam dalam pesantren juga nampak dalam kemandiriannya, dimana santri yang tinggal di asrama secara tidak langsung telah dididik dalam kemandirian, kesederhanaan, kebersihan, kedermawanan, toleransi, cara berbusana, dan gotong-royong. Dengan sederet aktifitasnya, mereka harus belajar membagi waktu, mengatur uang, belajar menempatkan diri, belajar bersosialisasi dengan lingkungan pesantren, belajar hidup sederhana (hidup di pesantren membiasakan diri dengan fasilitas apa adanya), belajar bertoleransi dengan sesama temannya, belajar gotong royong. Tuntutan untuk mampu hidup di pesantren inilah

${ }_{18}$ Abdullah Syukri Zarkasyi, "Peran Pesantren dalam Pendidikan Karakter Bangsa” dalam http://iprafuns.blogspot.com/2010/02 diakses 20 Juni 2015. 
yang menjadikan karakter dengan sendirinya tertanam dalam jiwa santri. Nilai karakter inilah yang menjadi kelebihan pesantren sehingga pendidikan pesantren hingga saat ini mendapatkan nilai prioritas di hati masyarkat.

\section{Peran Pesantren dalam Pendidikan Karakter}

Kehadiran pesantren tidak bisa lepas dari peran masyarakat sekitarnya yang merupakan ruang lingkup dan salah satu objek penentu dalam keberlangsungan pesantren. Oleh karena itu, pesantren akan berhadapan dengan gejala sosial yang sarat adanya perubahan. Perubahan sosial tentunya berdampak terhadap formulasi pesantren, karena pesantren juga merupakan lembaga sosial. Oleh karenanya, pesantren mau tidak mau harus berpartisipasi dalam mengatasi problem empiris masyarakat seperti kemiskinan, kebodohan, kerusakan lingkungan, keterbatasan sumber daya alam, degradasi moral, dan lainnya. Partisipasi ini perlu dilakukan agar kehadiran pesantren tetap relevan dengan perkembangan dan tuntuan masyarakat dan tidak mengalami disintegrasi dengan dinamika kehidupan sosial.

Sudah saatnya agama Islam dan lembaga-lembaga keagamaan seperti pesantren tampil ke depan dalam mengawal perubahan sosial. Dalam studi sosiologis (sosiologi agama) mereka dapat melakukan dua peranan peniting. Peranan tersebut meliputi: peran sebagai directive system dan sebagai defensive system. ${ }^{19}$

Dalam peran yang pertama directive system, agama ditempatkan sebagai referensi utama dalam proses perubahan. Dengan demikian, agama akan dapat berfungsi sebagai supremasi moralitas yang memberikan landasan dan kekuatan etik-spiritual masyarakat ketika mereka berdialektika dalam proses perubahan. Dengan pemaknaan semacam ini, agama tidak lagi dipandang sebagai penghambat perubahan, karena hakekatnya agama melekat dalam nilai-nilai kehidupan manusia. Maka seharusnya agama menjadi daya dorong yang kuat bagi terciptanya perubahan ke arah corak yang konstruktif dan humanistis bagi masa depan umat manusia.

Pesantren sebagai pusat pengembangan keagamaan harus mampu membekali santrinya dengan kemampuan religiusnya melalui penanaman nilai-nilai agama sebagaimana yang tertuang dalam kajian-kajian yang bersumber dari al-Qur'an dan Hadis. Penanaman nilai-nilai agama itu mesti ditanamkan sekokoh mungkin agar menjadi benteng yang kuat sehingga siap berkompetisi dalam dialektika kehidupan yang sarat adanya perubahan.

\footnotetext{
${ }^{19}$ Thomas O’Dea, Sosiology of Region (Terjemahan), (Jakarta: Rajawali, 1987), 132.
} 
Peran yang kedua, yaitu defensive system, agama menjadi semacam kekuatan kehidupan yang semakin kompleks di tengah derasnya arus peubahan. Masyarakat yang berpegang pada nilai-nilai religius akan mempunyai kemampuan untuk mempertahankan diri dan tidak ada rasa kekhawatiran serta keragu-raguan dalam menghadapi tantangan kehidupan.

Keterkaitan antara agama dengan aspek-aspek kehidupan pragmatis manusia menjadi wacana yang penah dikembangkankan oleh Abdurahman Wahid (Gus Dur). Dalam Bahasa Gusdur, agama dan lembaga-lembaga keagamaan perlu terlibat secara nyata dalam kegiatan pembangunan. Ada dua pendekatan dalam melihat kaitan antara agama dengan pembangunan. Pertama, pendekatan suplementer. Dengan pendekatan ini, agama dilihat sebagai penunjang pembangunan. Cara ini dilakukan dengan melegimitasi berbagai sasaran kerja yang sudah ditetapkan dalam perencanaan pembangunan. Dalam hal ini pesantren harus respon terhadap adanya peluang-peluang dalam rencana pembangunan misalnya dengan menyediakan sekolah dengan jurusan yang marketable. Kedua, pendekatan komplementer. Pendekatan ini melihat keterlibatan agama dan lembagalembaga agama diperlukan dalam menetapkan sasaran pembangunan, metode dan sasarannya. ${ }^{20}$

Pesantren sebagai salah satu lembaga yang memegang peranan penting dalam mentransfer konsepsi agama Islam, sudah seharusnya memiliki peran yang kuat dalam mengawal adanya perubahan sosial. Terlebih lagi kehadiran pesantren menjadi salah satu lembaga yang sangat diharapkan masyarakat dalam mewarnai corak perubahan sosial terutama dalam pembentukan karakter masyarakat. Oleh karenanya, pesantren mau tidak mau harus berani tampil menjadi lembaga sebagai agen of change (agen perubahan) yang mampu mewarnai eskalasi arus masyarakat yang sudah mulai tergerus oleh kekuatan Barat. Sementara kekuatan Barat memiliki kekuatan luar biasa yang mana dampaknya dapat mencerabut tatanan kehidupan sosial.

Penanaman konsep pendidikan karakter di pesantren secara konsisten dirasa mampu memgbendung laju budaya Barat. Karena pesantren memiliki pola pendidikan yang berbeda dengan pola pendidikan pada umumnya. Di pesantren terdapat pengawasan yang ketat menyangkut tata norma terutama tentang peribadatan khusus dan norma-norma muamalah tertentu.

Kekhasan pendidikan pesantren dipandang sebagai lembaga yang efektif dalam pembangunan akhlak. Di sinilah pesantren mengambil peran

20 Dedy Djamaluddin Malik dan Idi Subandy Ibrahim, Zaman Baru Islam Indonesia: Pemikiran dan Aksi Pollitik Abdurrahman Wahid, M Amien Rais, Nurcholis Majid dan Jalaluddin Rahmat, (Bandung: Zaman Wacana Mulia, 1998), 193. 
untuk menanggulangi berbagai persoalan khususnya krisis moral. Pesantrenlah sebuah lembaga yang titik tekannya bukan pada ranah kognitif saja, tetapi juga pada aspek afektif dan psikomotorik. Dengan demikian pesantren diharapkan mampu mencetak generasi berkarakter yang sarat dengan nilai-nilai agama yang menjadi pelopor pembangunan bangsa dengan identititas kesantriannya yang melekat pada dirinya.

Kiprah pesantren di tengah-tengah masyarakat dapat terwujud melaui peran-peran strategis pesantren. Peran strategis tersebut tercermin dalam fungsi pesantren seperti berikut:

1. Pesantren sebagai lembaga pendidikan keagamaan yang bertujuan untuk mentransfer dan mengembangkan ilmu-ilmu agama

2. Pesantren sebagai lembaga pengkaderan yang telah berhasil mencetak kader umat dan kader bangsa

3. Pesantren sebagai lembaga sosial yang mengajarkan anak didik (santri) hidup berkomunitas dengan lingkungan sosial di lingkungannya, mengajarkan bagaimana hakikat kehidupan

4. Pesantren sebagai agen reformasi sosial yang menciptakan perubahan dan perbaikan dalam kehidupan masyarakat.

Agar konsep pendidikan karakter di pesantren dapat berlangsung dengan maksimal, tentunya diperlukan formula dalam prakteknya. Doni Koesoema memberikan formula bahwa penddikan karakter jika ingin efektif dan utuh harus menyertakan tiga basis desain pemrogramannya yaitu; (1) desain pendidikan berbasis kelas, (2) desain pendidikan karakter berbasis kultur sekolah atau pesantren, dan (3) desain pendidikan karakter berbasis komunitas. $^{21}$

1. Desain pendidikan karakter berbasis kelas

Desain ini berbasis pada relasi para guru/ustad sebagai pendidik dan siswa/santri sebagai pelajar di dalam kelas. Konteks pendidikan karakter adalah proses relasional komunitas kelas dalam konteks pembelajaran. Relasi guru-pelajar bukan monolog, melainkan dialog dengan banyak arah sebab komunitas kelas terdiri atas guru dan siswa yang sama-sama berinteraksi dengan materi. Memberikan pemahaman dan pengertian akan keutamaan yang benar terjadi dalam konteks pengajaran ini, termasuk di dalamnya pula adalah ranah noninstruksional, seperti manajemen kelas, dan lain-lain, yang membantu terciptanya suasana yang nyaman. Dalam konteks pendidikan karakter di pesantren, kegiatan pembelajarn harian dilaksanakan di lingkungan masjid atau musholla ataupun ruangan tertentu yang dijadikan

\footnotetext{
${ }^{21}$ Doni Koesoema, “Pendidikan Karakter IntegraP’, Kompas, 11 Februari 2010, 1.
} 
tempat belajar dengan ustad yang bertindak sebagai fasilitator dan mediator pembelajaran

2. Desain pendidikan karakter berbasis sekolah/pesantren

Desain ini mencoba membangun kultur sekolah yang mampu membentuk karakter anak didik dengan bantuan pranata sosial sekolah/pesantren agar nilai terbentuk dan terbatinkan dalam diri siswa/santri.

Untuk menanamkan kejujuran misalnya, tidak cukup hanya dengan memberikan pesan-pesan moral kepada anak didik. Pesan moral ini mesti diperkuat dengan penciptaan kultur kejujuran melalui pembuatan tata peraturan sekolah yang tegas dan konsisten terhadap setiap perilaku ketidakjujuran. Dalam konteks pendidikan karakter berbasis kultur pesantren dilaksanakan dengan menata lingkungan fisik pesantren dan pembuatan tata tertib pesantren yang bernuansa nilai-nilai Islam.

3. Desain pendidikan karakter berbasis komunitas.

Dalam mendidik, komunitas sekolah/pesantren tidak berjuang sendirian. Masyarakat di luar lembaga/pesantren memiliki tanggung jawab moral untuk mengintegrasikan pembentukan karakter dalam konteks kehidupan mereka. Ketika lembaga lemah dalam penegakan hukum, ketika mereka yang bersalah tidak mendapatkan sanksi yang setimpal, lembaga telah mendidik masyarakatnya untuk menjadi manusia yang tidak menghargai makna tatanan sosial bersama. Dalam konteks pendidikan karakter di pesantren, implementasi desain pendidikan karakter berbasis komunitas dikembangkan dengan membuat kelompok-kelompok belajar dan mengembangkan program pengembangan diri.

Penerapan penndidikan karakter di pesantren tentunya akan bisa efektif jika tiga desain pendidikan karakter ini dilaksakan secara simultan dan sinergis. Mengabaikan ketiga desain tersebut, pendidikan hanya akan bersifat parsial, inkonsisten, dan tidak etektif.

\section{Epilog}

Perubahan sosial telah melahirkan banyak aspek ketimpangan dalam kehidupan sosial seperti adanya penyelewengan, tindak tindak kejahatan, dan sebagainya. Di saat degradasi moral semakin melanda bangsa ini, pesantren menjadi salah satu jawaban. Pesantren dengan desain pendidikannya yang khas mampu meramu aspek kognitif, afektik, dan psikomotorik menjadi sebuah kekuatan dalam karakter santri.

Pendidikan karakter atau lebih lekat dengan pendidikan budi pekerti (akhlak) dalam Islam merupakan keniscayaan guna mengurangi multidimensi yang melanda bangsa ini. agar efektif maka pendidikan 
karakter harus melibatkan tiga basis. Pertama basis kelas, dimana terjadi relasi antara guru dan peserta didik. Kedua, basis kultur sekolah/pesantren yaitu membangun kultur sekolah/pesantren yang mampu membentuk karakter peserta didik/santri. Ketiga, basis komunitas yaitu keluarga, masyarakat, dan negara menjadi bagian yang tidak bisa dilepaskan dari pendidikan karakter dalam membangun karakter yang tercermin dalam pola kehidupan sehari-hari.

Pesantren sebagai salah satu basis dalam pengembangan pendidikan karakter harus mampu mengimplementasikan pendidikan karakter dengan pendekatan holistik, yaitu mengintegrasikan perkembangan karakter ke dalam setiap aspek kehidupan santri dengan berbagai pendekatan. Di sinilah dibutuhkan keseriusan seluruh stake holder pesantren.

\section{Daftar Pustaka}

Gani, Bustami A dan Djohar Bahry, Dasar-Dasar Pokok Pendidikan Islam, Jakarta: Bulan Bintang, 1987.

Haedari, H. Amin, Transformasi Pesantren, Jakarta: Media Nusantara, 2007.

Koesoema, Doni. Pendidikan Karakter: Strategi Mendidik Anak di Zaman Mo-dern, Jakarta: PT Gasindo, 2007.

------.“Pendidikan Karakter Integral”, Kompas, 11 Februari 2010.

Lickona, Thomas. Educating for Character: How Our School Can Teach Respect and Responsibility, (New York; Bantam Books, 1991).

Malik, Dedy Djamaluddin dan Idi Subandy Ibrahim, Zaman Baaru Islam Indonesia: Pemikiran dan Aksi Pollitik Abdurrahman Wahid, M Amien Rais, Nurcholis Majid dan Jalaluddin Rahmat, (Bandung: Zaman Wacana Mulia, 1998).

Marzuki, Pendidikan Karakter Islam, Jakarta:Amzah, 2015.

Muslich, Masnur. Pendidikan Karakter Menjawab Tantangan Krisis Multidimensional, Jakarta: PT Bumi Aksara, 2011.

Nata, Abudin. Sejarah Pertumbuhan dan Perkembangan Lembaga-Lembaga Pendidikan Islam di Indoneisia, Jakarta: PT. Grasindo, 2001.

Saifuddin, Achmad Fedyani dan Karim, Mulyawan, Refleksi Karakter Bangsa, Jakarta: Forum Kajian Antropologi Indonesia, 2008.

Sidogiri, Tim Penulis Pustaka. Mengapa Saya Harus Mondok di Pesantren?, Pasuruan: Pustaka Sidogiri, 2008.

Sulthon, H. M. dan Moh. Khusuridlo, Manajemen Pondok Pesantren dalam Persefektif Global, Ygyakarta: LaksBang PRESSindo, 2006.

O’Dea, Thomas. Sosiology of Region (Terj), (Jakarta: Rajawali, 1987. 
Zarkasyi,Abdullah Syukri. Gontor dan Pembaharuan pendidikan Pesantren, Jakarta: PT Raja Grapindo Persada, 2005

------. "Peran Pesantren dalam Pendidikan Karakter Bangsa" dalam http://iprafuns.blogspot.com/2010/02 diakses 20 Juni 2015. 